\title{
Oral-recombinant Methioninase Converts an Osteosarcoma from Docetaxel-resistant to -Sensitive in a Clinically-relevant Patient-derived Orthotopic-xenograft (PDOX) Mouse Model
}

\author{
YUSUKE AOKI ${ }^{1,2,3}$, YASUNORI TOME ${ }^{3}$, NATHANIEL F. WU ${ }^{1,4}$, JUN YAMAMOTO $^{1,2}$, KAZUYUKI HAMADA $^{1,2}$, \\ QINGHONG HAN ${ }^{1}$, MICHAEL BOUVET ${ }^{2}$, KOTARO NISHIDA ${ }^{3}$ and ROBERT M. HOFFMAN ${ }^{1,2}$ \\ ${ }^{1}$ AntiCancer Inc, San Diego, CA, U.S.A.; \\ ${ }^{2}$ Department of Surgery, University of California, San Diego, La Jolla, CA, U.S.A.; \\ ${ }^{3}$ Department of Orthopedic Surgery, Graduate School of Medicine, University of the Ryukyus, Okinawa, Japan; \\ ${ }^{4}$ Department of Molecular and Cellular Biology, Harvard University, Cambridge, MA, U.S.A.
}

\begin{abstract}
Background/Aim: Osteosarcoma is the most frequent malignant bone tumor. Failure of first-line therapy results in poor prognosis of osteosarcoma. In the present report, we examined the efficacy of the combination of oral recombinant methioninase (o-rMETase) and docetaxel (DOC) on an osteosarcoma patient-derived orthotopic xenograft (PDOX) mouse model. Materials and Methods: Osteosarcoma-PDOX models were established by tumor insertion within the tibia of nude mice. The osteosarcoma PDOX models were randomized into four groups (4-5 mice per group): control; o-rMETae alone; DOC alone; o- rMETase combined with DOC. The treatment period was 3 weeks. Results: The combination of o-rMETase and DOC showed significant efficacy compared to the control group $(p=0.03)$. In contrast, there was no significant efficacy of $o$ rMETase alone or DOC alone ( $p=0.65,0.60$, respectively). Conclusion: o-rMETase converted an osteosarcoma PDOX from DOC-resistant to -sensitive. This combination therapy may be effective against recalcitrant osteosarcoma and other recalcitrant cancers.
\end{abstract}

Osteosarcoma is classified as a rare cancer, but it is the most frequent malignant bone tumor. Failure of first-line therapy results in very poor prognosis of osteosarcoma patients (1-4).

This article is freely accessible online.

Correspondence to: Robert M. Hoffman, AntiCancer Inc, 7917 Ostrow St, San Diego, CA, 92111, U.S.A. Tel: +1 8586542555, e-mail: all@anticancer.com; Yasunori Tome, Department of Orthopedic Surgery, Graduate School of Medicine, University of the Ryukyus, 207 Uehara, Nishihara, Okinawa, 903-0125, Japan. Tel: +81 988953331, e-mail: yastome@med.u-ryukyu.ac.jp

Key Words: Osteosarcoma, nude mice, PDOX, methionine, methioninase, docetaxel, combination therapy, efficacy.
In order to individualize and improve therapy for recalcitrant osteosarcoma, our laboratory has established a patient-derived orthotopic xenograft (PDOX) mouse model of osteosarcoma to identify potential effective treatment strategies (5-20).

Methionine addiction (21) is a fundamental and general hallmark of cancer, resulting in the requirement of very high levels of methionine compared to normal cells (21-26). Methionine addiction of cancer is termed the Hoffman effect (27-29), which is analogous to the glucose addiction of cancer cells, termed the Warburg effect. The methioninedegrading enzyme, recombinant methioninase (rMETase), effectively targets methionine addiction to inhibit or arrest cancer cells in late- $\mathrm{S} / \mathrm{G}_{2}$ phases of the cell cycle (30-36).

Docetaxel (DOC) arrests cells in the M-phase of the cell cycle (37), complementing the effect of rMETase (38). The efficacy of the combination of DOC and gemcitabine (GEM) in osteosarcoma, especially in relapsed or refractory cases, has been reported (37). DOC has also shown synergy with AG-270, an inhibitor of methionine adenosyl-transferase $2 \alpha$ (MAT2A), which is involved in methionine addiction (39).

In 2018, our laboratory discovered that rMETase could be effectively administrated orally (o-rMETase) (32), which greatly facilitated treatment of recalcitrant cancer in both PDOX models and patients $(19,20,32-34,40-57)$.

In the present study, we examined whether the combination of o-rMETase and DOC is effective in an osteosarcomaPDOX mouse model.

\section{Materials and Methods}

Mice. Athymic nu/nu nude mice in the present study, (AntiCancer, Inc., San Diego, CA, USA), 4-6week old, were used as previously described (5-20), with Institutional Animal Care and Use Committee (IACUC) approval, following the principles and procedures provided in the National Institutes of Health (NIH) Guide for the Care and Use of Animals, under Assurance Number A3873-1 (5-20). 
Patient-derived tumor. An osteosarcoma biopsy specimen from a 14-yearold boy with pelvic osteosarcoma was previously surgically obtained from the UCLA Medical Center after patient and parent informed written consent and Institutional Review Board approval (IRB\#10-001857) and established in nude mice as previously reported (20).

Tibia-insertion osteosarcoma PDOX model. A 1-mm diameter medullary cavity was made in the proximal tibia and $1 \mathrm{~mm}^{3}$ tumor fragments, previously grown subcutaneously in nude mice, were implanted into the medullary cavity, as previously described (58).

Recombinant methioninase (rMETase) production. The protocol for the production of rMETase has been previously reported (59).

Treatment study design. The osteosarcoma-PDOX mouse models were randomized into four groups of four or five mice per group as follows: G1, control PBS (0.2 ml/day, oral, twice a day); G2, orMETase (50 units/mouse, oral, twice a day); G3, DOC [20 mg/kg, intraperitoneal (i.p.) injection, once a week]; G4, combination of orMETase (50 units, oral, twice a day) and DOC $(20 \mathrm{mg} / \mathrm{kg}$, i.p. injection, once a week). The treatment was initiated once tumor size reached a volume of $40 \mathrm{~mm}^{3}$. Tumor measurement and tumorvolume calculation were performed as previously described (5-20). The treatment period was 3 weeks for each group, and all mice were sacrificed after treatment as previously described (5-20) (Figure 1). Data are presented as mean \pm standard deviation.

Hematoxylin and eosin $(H \& E)$ staining. Procedures for $\mathrm{H} \& \mathrm{E}$ staining were performed according to standard protocols.

Statistical analyses. All statistical analyses were performed with JMP ver. 15.0.0 (SAS Institute, Cary, NC, USA). Welch's $t$-test was applied as the parametric test to compare the means between two related groups. Tukey-Kramer HSD was performed for the parametric test of comparison between groups. Bar graphs show the mean, and error bars indicate standard deviation of the mean. A $p$ value $\leq 0.05$ was defined as statistically significant.

\section{Results}

Treatment efficacy on the osteosarcoma PDOX. There were no significant differences in tumor volume of the osteosarcomaPDOX between the control and those treated with o-rMETase alone, or DOC alone, at the end of the treatment period ( $p=0.65$, 0.60 , respectively). In contrast, the combination of o-rMETase and DOC showed significant efficacy to reduce tumor volume compared to the control group ( $p=0.03$ ) (Figure 2). There were no animal deaths in any group. Mouse weight showed no significant differences between the four groups (Figure 3).

Histology of osteosarcoma-PDOX. The osteosarcoma-PDOX tissue of the control group comprised high-density spindleshaped cancer cells (Figure 4A). Treatment with o-rMETasealone or DOC alone had no effect on the histologic phenotype of the osteosarcoma PDOX, which was similar to the control. Treatment with the combination of DOC and orMETase reduced cancer-cell density in the osteosarcoma PDOX (Figure 4B-D).

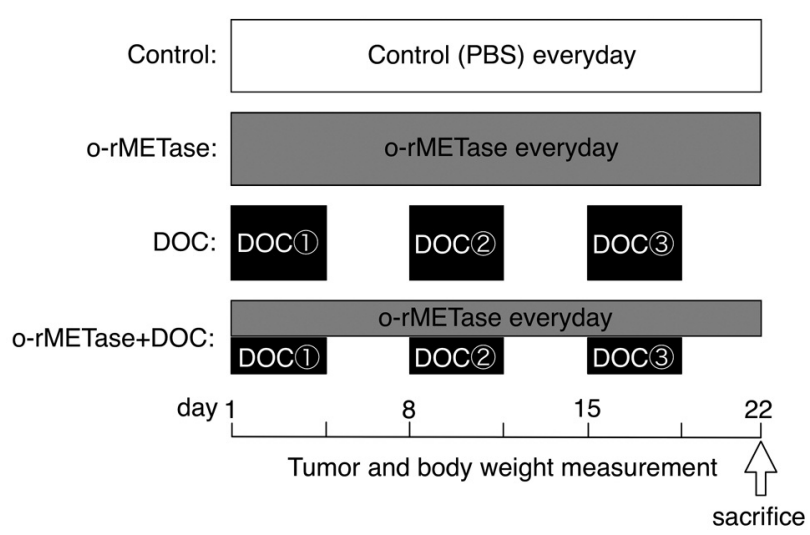

Figure 1. Treatment scheme.

\section{Discussion}

The present study showed that o-rMETase converted an osteosarcoma PDOX from DOC-resistant to -sensitive. The combination of DOC and GEM has shown efficacy as secondline therapy for soft-tissue sarcoma, following failure of firstline treatment with doxorubicin (DOX) and ifosfamide (IFO) (60). In the present study, DOC alone had no efficacy on the osteosarcoma PDOX, but it was highly effective in combination with o-rMETase. The present study was performed in a clinically-relevant osteosarcoma PDOX model, compared to an un-physiological subcutaneous-tumor model of sarcoma (61).

The present results are consistent with a previous study reporting that the combination of $\mathrm{AG}-270$, a methionine adenosyltransferase $2 \alpha$ (MAT2A) inhibitor, with DOC showed efficacy on non-small-cell lung carcinoma (NSCLC) and esophageal squamous cell carcinoma (SCC) in patientderived xenograft (PDX) models, where neither DOC alone nor AG-270 alone showed significant efficiency (39).

AG-270 targets methionine addiction, as does o-rMETase, and the efficacy of the combination of AG-270 and DOC suggested that the combination of o-rMETase and DOC would be effective. Indeed, our present results confirmed this hypothesis. o-rMETase and DOC are complementary as orMETase selectively arrests cancer cells in late-S/G $\mathrm{G}_{2}$-phases of the cell cycle $(35,36)$, DOC arrests cells in the M phases (37). The combination of methionine restriction and an anti-mitotitc has been previously shown to be selectively effective on cancer cells on a co-culture of cancer and normal cells, as cancer cells which escaped from the late- $\mathrm{S} / \mathrm{G}_{2}$ arrest by methionine restriction were arrested by the antimitotic in M phase (38).

The present results suggest that the combination of o-rMETase and DOC should be effective against recalcitrant osteosarcoma and other recalcitrant cancers. o-rMETase and combination chemotherapy for blockade of the methioninemethylation axis $(40,41)$ is also a promising strategy as o-rMETase has shown clinical efficacy (33). 


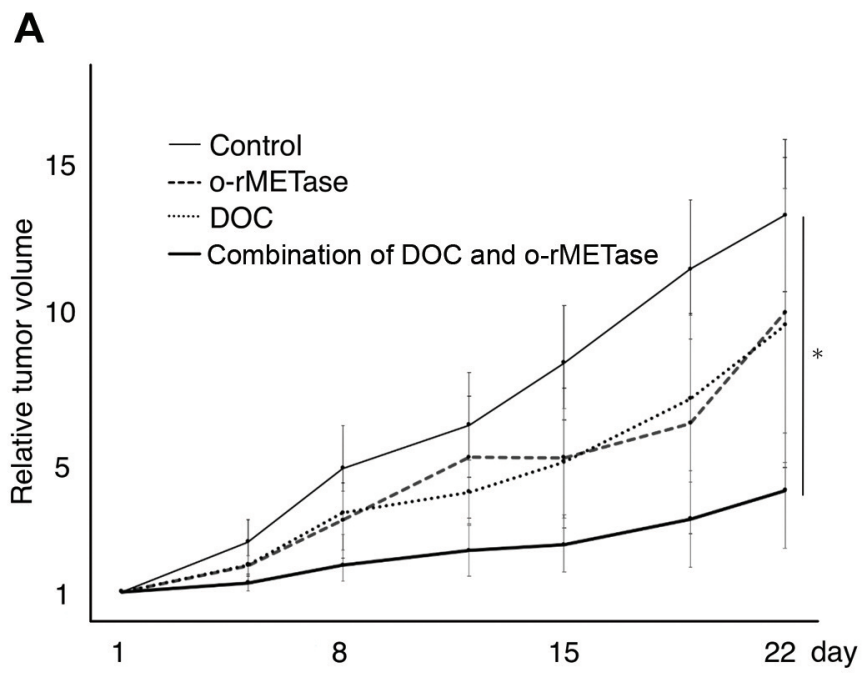

B
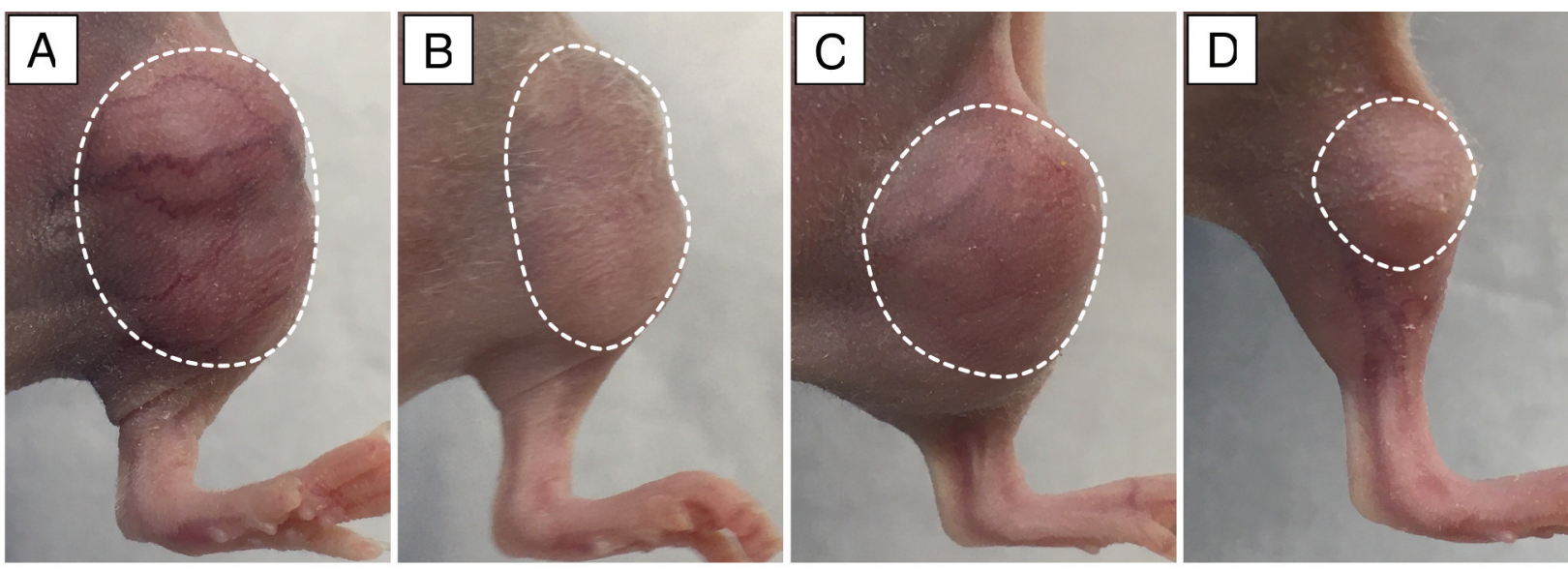

Figure 2. A: Efficacy of drugs on the osteosarcoma-PDOX. Line graphs show relative tumor volume at each time point. Relative tumor volume is defined as the tumor volume at time $(t)$ divided by the tumor volume at the onset of treatment. $n=4-5$ mice/group. ${ }^{*} p<0.05$. Error bars: $\pm S D$. B: Representative photographs of osteosarcoma-PDOX mouse models from each treatment group at the end of treatment. A: Untreated control; B: orMETase alone; C: DOC; D: o-rMETase and DOC.

\section{Conflicts of Interest}

The Authors have no conflicts of interest to declare in relation to this study.

\section{Authors' Contributions}

YA, YT and RMH were involved in study conception and design. YA and NFW were involved in acquisition of data. YA, YT, NFW, JY, KH and RMH analyzed and interpreted data. YA, YT and RMH wrote this manuscript. All Authors reviewed and approved the manuscript.

\section{Acknowledgements}

This paper is dedicated to the memory of A. R. Moossa, MD, Sun Lee, MD, Professor Li Jiaxi and Masaki Kitajima, MD, and Sun Lee, MD.

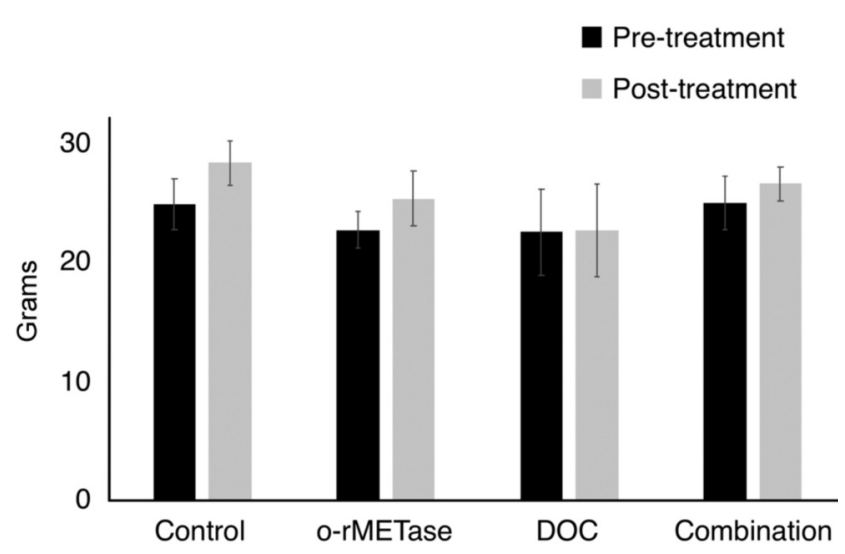

Figure 3. Mouse body weight at pre-and post-treatment. 

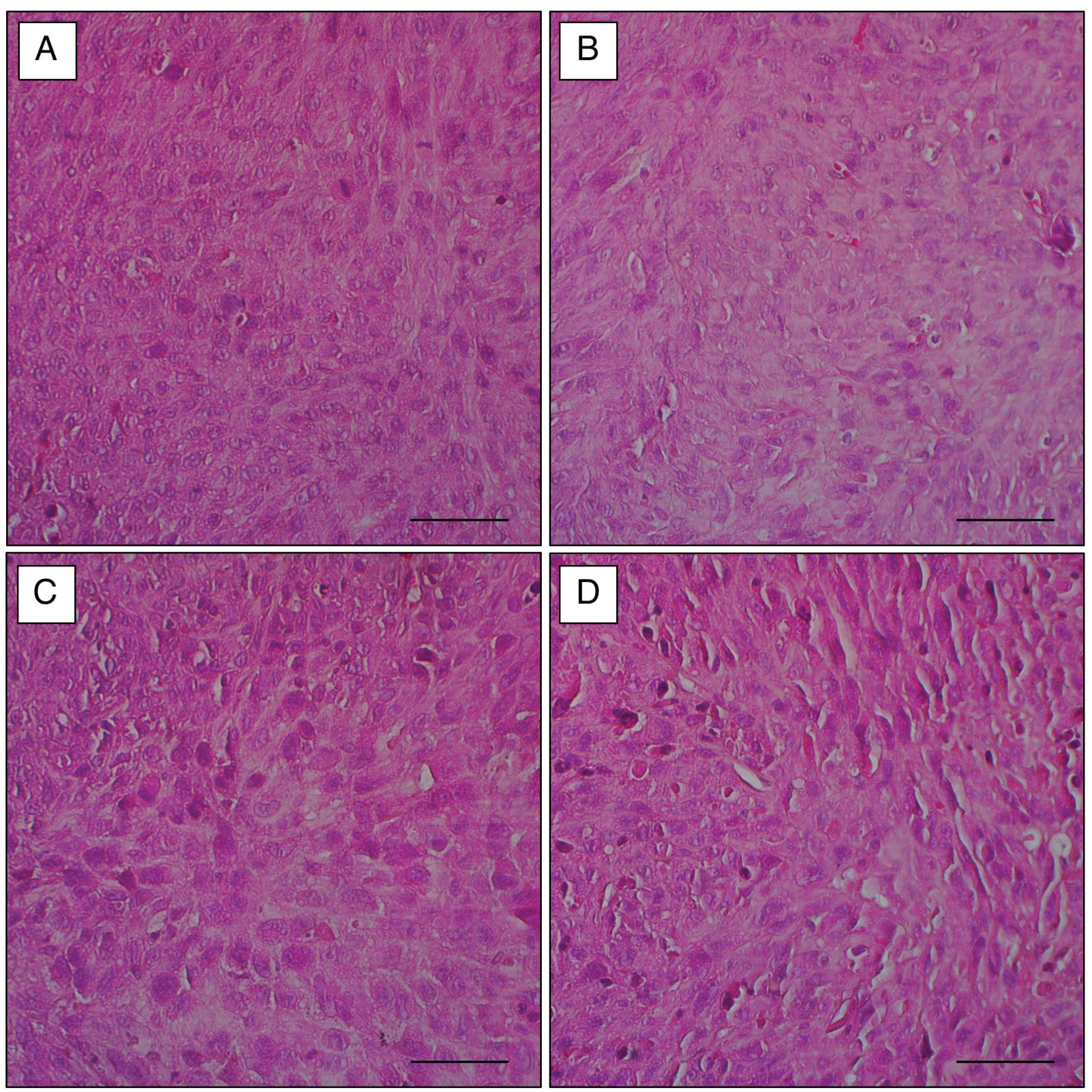

Figure 4. Representative photomicrographs of $H \&$ E-stained tissue sections of the untreated and treated osteosarcoma-PDOX. (A) Control administered oral PBS. (B) o-rMETase. (C) DOC. (D) Combination of o-rMETase and DOC. Magnification: 200x. Scale bar: $50 \mu \mathrm{m}$.

\section{References}

1 Misaghi A, Goldin A, Awad M and Kulidjian AA: Osteosarcoma: A comprehensive review. SICOT J 4: 12, 2018. PMID: 29629690. DOI: $10.1051 / \operatorname{sicotj} / 2017028$

2 Sampson VB, Gorlick R, Kamara D and Anders Kolb E: A review of targeted therapies evaluated by the pediatric preclinical testing program for osteosarcoma. Front Oncol 3: 132, 2013. PMID: 23755370. DOI: 10.3389/fonc.2013.00132

3 Zhao J, Dean DC, Hornicek FJ, Yu X and Duan Z: Emerging next-generation sequencing-based discoveries for targeted osteosarcoma therapy. Cancer Lett 474: 158-167, 2020. PMID: 31987920. DOI: 10.1016/j.canlet.2020.01.020

4 Meyers PA, Schwartz CL, Krailo M, Kleinerman ES, Betcher D, Bernstein ML, Conrad E, Ferguson W, Gebhardt M, Goorin AM, Harris MB, Healey J, Huvos A, Link M, Montebello J, Nadel H, Nieder M, Sato J, Siegal G, Weiner M, Wells R, Wold L, Womer $\mathrm{R}$ and Grier $\mathrm{H}$ : Osteosarcoma: A randomized, prospective trial of the addition of ifosfamide and/or muramyl tripeptide to cisplatin, doxorubicin, and high-dose methotrexate. J Clin Oncol 23(9): 2004-2011, 2005. PMID: 15774791. DOI: 10.1200/JCO.2005.06.031 
5 Igarashi K, Kawaguchi K, Yamamoto N, Hayashi K, Kimura H, Miwa S, Higuchi T, Taniguchi Y, Yonezawa H, Araki Y, Morinaga S, Misra S, Nelson SD, Dry SM, Li Y, Odani A, Singh SR, Tsuchiya H and Hoffman RM: A novel anionic-phosphateplatinum complex effectively targets a cisplatinum-resistant osteosarcoma in a patient-derived orthotopic xenograft mouse model. Cancer Genomics Proteomics 17(3): 217-223, 2020 PMID: 32345663. DOI: 10.21873/cgp.20182

6 Higuchi T, Yamamoto J, Sugisawa N, Tashiro Y, Nishino H, Yamamoto N, Hayashi K, Kimura H, Miwa S, Igarashi K, Bouvet M, Singh SR, Tsuchiya H and Hoffman RM: PPAR $\gamma$ agonist pioglitazone in combination with cisplatinum arrests a chemotherapy-resistant osteosarcoma PDOX model. Cancer Genomics Proteomics 17(1): 35-40, 2020. PMID: 31882549 DOI: $10.21873 / \operatorname{cgp} .20165$

7 Higuchi T, Sugisawa N, Miyake K, Oshiro H, Yamamoto N, Hayashi K, Kimura H, Miwa S, Igarashi K, Kline Z, Bouvet M, Singh SR, Tsuchiya H and Hoffman RM: Pioglitazone, an agonist of PPAR $\gamma$, reverses doxorubicin-resistance in an osteosarcoma patient-derived orthotopic xenograft model by downregulating Pglycoprotein expression. Biomed Pharmacother 118: 109356, 2019. PMID: 31545293. DOI: 10.1016/j.biopha.2019.109356

8 Higuchi T, Sugisawa N, Miyake K, Oshiro H, Yamamoto N, Hayashi K, Kimura H, Miwa S, Igarashi K, Kline Z, Belt P, Chawla SP, Bouvet M, Singh SR, Tsuchiya H and Hoffman RM: Combination treatment with sorafenib and everolimus regresses a doxorubicin-resistant osteosarcoma in a PDOX mouse model Anticancer Res 39(9): 4781-4786, 2019. PMID: 31519579. DOI: 10.21873/anticanres.13662

9 Kiyuna T, Tome Y, Miyake K, Murakami T, Oshiro H, Igarashi K, Kawaguchi K, Hsu J, Singh M, Li Y, Nelson S, Bouvet M, Singh SR, Kanaya F and Hoffman RM: Eribulin suppressed cisplatinum- and doxorubicin-resistant recurrent lung metastatic osteosarcoma in a patient-derived orthotopic xenograft mouse model. Anticancer Res 39(9): 4775-4779, 2019. PMID: 31519578. DOI: 10.21873 /anticanres.13661

10 Higuchi T, Sugisawa N, Miyake K, Oshiro H, Yamamoto N, Hayashi K, Kimura H, Miwa S, Igarashi K, Chawla SP, Bouvet M, Singh SR, Tsuchiya H and Hoffman RM: Sorafenib and palbociclib combination regresses a cisplatinum-resistant osteosarcoma in a PDOX mouse model. Anticancer Res 39(8): 4079-4084, 2019. PMID: 31366491. DOI: 10.21873/anticanres.13565

11 Higuchi T, Sugisawa N, Miyake K, Oshiro H, Yamamoto N, Hayashi K, Kimura H, Miwa S, Igarashi K, Bouvet M, Singh SR, Tsuchiya $\mathrm{H}$ and Hoffman RM: The combination of olaratumab with doxorubicin and cisplatinum regresses a chemotherapyresistant osteosarcoma in a patient-derived orthotopic xenograft mouse model. Transl Oncol 12(9): 1257-1263, 2019. PMID: 31299622. DOI: 10.1016/j.tranon.2019.06.002

12 Higuchi T, Miyake K, Oshiro H, Sugisawa N, Yamamoto N, Hayashi K, Kimura H, Miwa S, Igarashi K, Chawla SP, Bouvet M, Singh SR, Tsuchiya H and Hoffman RM: Trabectedin and irinotecan combination regresses a cisplatinum-resistant osteosarcoma in a patient-derived orthotopic xenograft nudemouse model. Biochem Biophys Res Commun 513(2): 326-331, 2019. PMID: 30955860. DOI: 10.1016/j.bbrc.2019.03.191

13 Igarashi K, Kawaguchi K, Kiyuna T, Miyake K, Miyake M, Li Y, Nelson SD, Dry SM, Singh AS, Elliott IA, Russell TA, Eckardt MA, Yamamoto N, Hayashi K, Kimura H, Miwa S, Tsuchiya H, Eilber FC and Hoffman RM: Temozolomide combined with irinotecan regresses a cisplatinum-resistant relapsed osteosarcoma in a patient-derived orthotopic xenograft (PDOX) precisiononcology mouse model. Oncotarget 9(8): 7774-7781, 2017. PMID: 29487690. DOI: 10.18632/oncotarget.22892

14 Igarashi K, Kawaguchi K, Kiyuna T, Miyake K, Miyake M, Li S, Han Q, Tan Y, Zhao M, Li Y, Nelson SD, Dry SM, Singh AS, Elliott IA, Russell TA, Eckardt MA, Yamamoto N, Hayashi K, Kimura H, Miwa S, Tsuchiya H, Eilber FC and Hoffman RM: Tumor-targeting Salmonella typhimurium A1-R combined with recombinant methioninase and cisplatinum eradicates an osteosarcoma cisplatinum-resistant lung metastasis in a patient-derived orthotopic xenograft (PDOX) mouse model: Decoy, trap and kill chemotherapy moves toward the clinic. Cell Cycle 17(6): 801-809, 2018. PMID: 29374999. DOI: 10.1080/15384101.2018.1431596

15 Igarashi K, Murakami T, Kawaguchi K, Kiyuna T, Miyake K, Zhang Y, Nelson SD, Dry SM, Li Y, Yanagawa J, Russell TA, Singh AS, Tsuchiya H, Elliott I, Eilber FC and Hoffman RM: A patient-derived orthotopic xenograft (PDOX) mouse model of a cisplatinum-resistant osteosarcoma lung metastasis that was sensitive to temozolomide and trabectedin: Implications for precision oncology. Oncotarget 8(37): 62111-62119, 2017. PMID: 28977930. DOI: 10.18632/oncotarget.19095

16 Igarashi K, Kawaguchi K, Kiyuna T, Miyake K, Murakami T, Yamamoto N, Hayashi K, Kimura H, Miwa S, Tsuchiya H and Hoffman RM: Effective metabolic targeting of human osteosarcoma cells in vitro and in orthotopic nude-mouse models with recombinant methioninase. Anticancer Res 37(9): 48074812, 2017. PMID: 28870899. DOI: 10.21873/anticanres.11887

17 Igarashi K, Kawaguchi K, Murakami T, Kiyuna T, Miyake K, Nelson SD, Dry SM, Li Y, Yanagawa J, Russell TA, Singh AS, Yamamoto N, Hayashi K, Kimura H, Miwa S, Tsuchiya H, Eilber FC and Hoffman RM: Intra-arterial administration of tumortargeting Salmonella typhimurium A1-R regresses a cisplatinresistant relapsed osteosarcoma in a patient-derived orthotopic xenograft (PDOX) mouse model. Cell Cycle 16(12): 1164-1170, 2017. PMID: 28494180. DOI: 10.1080/15384101.2017.1317417

18 Murakami T, Igarashi K, Kawaguchi K, Kiyuna T, Zhang Y, Zhao M, Hiroshima Y, Nelson SD, Dry SM, Li Y, Yanagawa J, Russell T, Federman N, Singh A, Elliott I, Matsuyama R, Chishima T, Tanaka K, Endo I, Eilber FC and Hoffman RM: Tumor-targeting Salmonella typhimurium A1-R regresses an osteosarcoma in a patient-derived xenograft model resistant to a molecular-targeting drug. Oncotarget 8(5): 8035-8042, 2017. PMID: 28030831. DOI: 10.18632/oncotarget.14040

19 Higuchi T, Sugisawa N, Yamamoto J, Oshiro H, Han Q, Yamamoto N, Hayashi K, Kimura H, Miwa S, Igarashi K, Tan Y, Kuchipudi S, Bouvet M, Singh SR, Tsuchiya H and Hoffman RM: The combination of oral-recombinant methioninase and azacitidine arrests a chemotherapy-resistant osteosarcoma patient-derived orthotopic xenograft mouse model. Cancer Chemother Pharmacol 85(2): 285291, 2020. PMID: 31705268. DOI: 10.1007/s00280-019-03986-0

20 Higuchi T, Oshiro H, Miyake K, Sugisawa N, Han Q, Tan Y, Park J, Zhang Z, Razmjooei S, Yamamoto N, Hayashi K, Kimura H, Miwa S, Igarashi K, Bouvet M, Chawla SP, Singh SR, Tsuchiya H and Hoffman RM: Oral recombinant methioninase, combined with oral caffeine and injected cisplatinum, overcome cisplatinumresistance and regresses patient-derived orthotopic xenograft model of osteosarcoma. Anticancer Res 39(9): 4653-4657, 2019. PMID: 31519563. DOI: 10.21873/anticanres.13646 
21 Hoffman RM and Erbe RW: High in vivo rates of methionine biosynthesis in transformed human and malignant rat cells auxotrophic for methionine. Proc Natl Acad Sci USA 73(5): 1523-1527, 1976. PMID: 179090. DOI: 10.1073/pnas.73.5.1523

22 Coalson DW, Mecham JO, Stern PH and Hoffman RM: Reduced availability of endogenously synthesized methionine for Sadenosylmethionine formation in methionine-dependent cancer cells. Proc Natl Acad Sci USA 79(14): 4248-4251, 1982. PMID: 6289297. DOI: 10.1073/pnas.79.14.4248

23 Stern $\mathrm{PH}$ and Hoffman RM: Elevated overall rates of transmethylation in cell lines from diverse human tumors. In Vitro 20(8): 663-670, 1984. PMID: 6500606. DOI: 10.1007/ BF02619617

24 Yamamoto J, Han Q, Inubushi S, Sugisawa N, Hamada K, Nishino H, Miyake K, Kumamoto T, Matsuyama R, Bouvet M, Endo I and Hoffman RM: Histone methylation status of $\mathrm{H} 3 \mathrm{~K} 4 \mathrm{me} 3$ and $\mathrm{H} 3 \mathrm{~K} 9 \mathrm{me} 3$ under methionine restriction is unstable in methionine-addicted cancer cells, but stable in normal cells. Biochem Biophys Res Commun 533(4): 10341038, 2020. PMID: 33019978. DOI: 10.1016/j.bbrc.2020.09.108

25 Mecham JO, Rowitch D, Wallace CD, Stern PH and Hoffman RM: The metabolic defect of methionine dependence occurs frequently in human tumor cell lines. Biochem Biophys Res Commun 117(2): 429-434, 1983. PMID: 6661235. DOI: $10.1016 / 0006-291 \times(83) 91218-4$

26 Tan Y, Xu M and Hoffman RM: Broad selective efficacy of rMETase and PEG-rMETase on cancer cells in vitro. Anticancer Res 30(3): 793-798, 2010. PMID: 20392998.

27 Kaiser P: Methionine Dependence of Cancer. Biomolecules 10(4): 568, 2020. PMID: 32276408. DOI: 10.3390/biom 10040568

28 Lauinger L and Kaiser P: Sensing and signaling of methionine metabolism. Metabolites 11(2): 83, 2021. PMID: 33572567. DOI: $10.3390 /$ metabo11020083

29 Borrego SL, Fahrmann J, Hou J, Lin DW, Tromberg BJ, Fiehn $\mathrm{O}$ and Kaiser P: Lipid remodeling in response to methionine stress in MDA-MBA-468 triple-negative breast cancer cells. J Lipid Res 100056, 2021. PMID: 33647277. DOI: 10.1016/j.jlr.

30 Yoshioka T, Wada T, Uchida N, Maki H, Yoshida H, Ide N, Kasai H, Hojo K, Shono K, Maekawa R, Yagi S, Hoffman RM and Sugita $\mathrm{K}$ : Anticancer efficacy in vivo and in vitro, synergy with 5-fluorouracil, and safety of recombinant methioninase. Cancer Res 58(12): 2583-2587, 1998. PMID: 9635582.

31 Kokkinakis DM, Hoffman RM, Frenkel EP, Wick JB, Han Q, Xu M, Tan Y and Schold SC: Synergy between methionine stress and chemotherapy in the treatment of brain tumor xenografts in athymic mice. Cancer Res 61(10): 4017-4023, 2001. PMID: 11358820 .

32 Kawaguchi K, Miyake K, Han Q, Li S, Tan Y, Igarashi K, Kiyuna T, Miyake M, Higuchi T, Oshiro H, Zhang Z, Razmjooei S, Wangsiricharoen S, Bouvet M, Singh SR, Unno M and Hoffman RM: Oral recombinant methioninase (o-rMETase) is superior to injectable rMETase and overcomes acquired gemcitabine resistance in pancreatic cancer. Cancer Lett 432: 251-259, 2018. PMID: 29928962. DOI: 10.1016/j.canlet.2018.06.016

33 Han Q, Tan Y and Hoffman RM: Oral dosing of recombinant methioninase is associated with a $70 \%$ drop in PSA in a patient with bone-metastatic prostate cancer and 50\% reduction in circulating methionine in a high-stage ovarian cancer patient. Anticancer Res 40(5): 2813-2819, 2020. PMID: 32366428. DOI: 10.21873 /anticanres. 14254
34 Yamamoto J, Miyake K, Han Q, Tan Y, Inubushi S, Sugisawa N, Higuchi T, Tashiro Y, Nishino H, Homma Y, Matsuyama R, Chawla SP, Bouvet M, Singh SR, Endo I and Hoffman RM: Oral recombinant methioninase increases TRAIL receptor-2 expression to regress pancreatic cancer in combination with agonist tigatuzumab in an orthotopic mouse model. Cancer Lett 492: 174184, 2020. PMID: 32739322. DOI: 10.1016/j.canlet.2020.07.034

35 Hoffman RM and Jacobsen SJ: Reversible growth arrest in simian virus 40-transformed human fibroblasts. Proc Natl Acad Sci USA 77(12): 7306-7310, 1980. PMID: 6261250. DOI: 10.1073/pnas.77.12.7306

36 Yano S, Li S, Han Q, Tan Y, Bouvet M, Fujiwara T and Hoffman RM: Selective methioninase-induced trap of cancer cells in S/G2 phase visualized by FUCCI imaging confers chemosensitivity. Oncotarget 5(18): 8729-8736, 2014. PMID: 25238266. DOI: 10.18632/oncotarget.2369

37 Zhang Y, Yang J, Zhao N, Wang C, Kamar S, Zhou Y, He Z, Yang J, Sun B, Shi X, Han L and Yang Z: Progress in the chemotherapeutic treatment of osteosarcoma. Oncol Lett 16(5): 6228-6237, 2018. PMID: 30405759. DOI: 10.3892/ol.2018.9434

38 Stern PH and Hoffman RM: Enhanced in vitro selective toxicity of chemotherapeutic agents for human cancer cells based on a metabolic defect. J Natl Cancer Inst 76(4): 629-639, 1986. PMID: 3457200. DOI: 10.1093/jnci/76.4.629

39 Kalev P, Hyer ML, Gross S, Konteatis Z, Chen CC, Fletcher M, Lein M, Aguado-Fraile E, Frank V, Barnett A, Mandley E, Goldford J, Chen Y, Sellers K, Hayes S, Lizotte K, Quang P, Tuncay Y, Clasquin M, Peters R, Weier J, Simone E, Murtie J, Liu W, Nagaraja R, Dang L, Sui Z, Biller SA, Travins J, Marks KM and Marjon K: MAT2A inhibition blocks the growth of MTAP-deleted cancer cells by reducing PRMT5-dependent mRNA splicing and inducing DNA damage. Cancer Cell 39(2): 209-224.e11, 2021. PMID: 33450196. DOI: 10.1016/j.ccell.2020.12.010

40 Higuchi T, Han Q, Sugisawa N, Yamamoto J, Yamamoto N, Hayashi K, Kimura H, Miwa S, Igarashi K, Bouvet M, Singh SR, Tsuchiya $\mathrm{H}$ and Hoffman RM: Combination methioninemethylation-axis Blockade: A Novel approach to target the methionine addiction of cancer. Cancer Genomics Proteomics 18(2):113-120, 2021. PMID: 33608308. DOI:10.21873/cgp.20246

41 Sugisawa N, Yamamoto J, Han Q, Tan Y, Tashiro Y, Nishino H, Inubushi S, Hamada K, Kawaguchi K, Unno M, Bouvet M and Hoffman RM: Triple-methyl blockade with recombinant methioninase, cycloleucine, and azacitidine arrests a pancreatic cancer patient-derived orthotopic xenograft model. Pancreas 50(1): 93-98, 2021. PMID: 33370029. DOI: 10.1097/MPA.0000000000001709

42 Kawaguchi K, Higuchi T, Li S, Han Q, Tan Y, Igarashi K, Zhao M, Miyake K, Kiyuna T, Miyake M, Ohshiro H, Sugisawa N, Zhang Z, Razmjooei S, Wangsiricharoen S, Chmielowski B, Nelson SD, Russell TA, Dry SM, Li Y, Eckardt MA, Singh AS, Singh SR, Eilber FC, Unno M and Hoffman RM: Combination therapy of tumor-targeting Salmonella typhimurium A1-R and oral recombinant methioninase regresses a BRAF-V600E-negative melanoma. Biochem Biophys Res Commun 503(4): 3086-3092, 2018. PMID: 30166061. DOI: 10.1016/j.bbrc.2018.08.097

43 Higuchi T, Kawaguchi K, Miyake K, Han Q, Tan Y, Oshiro H, Sugisawa N, Zhang Z, Razmjooei S, Yamamoto N, Hayashi K, Kimura H, Miwa S, Igarashi K, Chawla SP, Singh AS, Eilber FC, Singh SR, Tsuchiya $\mathrm{H}$ and Hoffman RM: Oral recombinant methioninase combined with caffeine and doxorubicin induced 
regression of a doxorubicin-resistant synovial sarcoma in a PDOX mouse model. Anticancer Res 38(10): 5639-5644, 2018. PMID: 30275182. DOI: 10.21873/anticanres.12899

44 Miyake K, Kiyuna T, Li S, Han Q, Tan Y, Zhao M, Oshiro H, Kawaguchi K, Higuchi T, Zhang Z, Razmjooei S, Barangi M, Wangsiricharoen S, Murakami T, Singh AS, Li Y, Nelson SD, Eilber FC, Bouvet M, Hiroshima Y, Chishima T, Matsuyama R, Singh SR, Endo I and Hoffman RM: Combining tumor-selective bacterial therapy with Salmonella typhimurium A1-R and cancer metabolism targeting with oral recombinant methioninase regressed an Ewing's sarcoma in a patient-derived orthotopic Xenograft model. Chemotherapy 63(5): 278-283, 2018. PMID: 30673664. DOI: $10.1159 / 000495574$

45 Hoffman RM, Han Q, Kawaguchi K, Li S and Tan Y: Afterword: Oral methioninase-answer to cancer and fountain of youth? Methods Mol Biol 1866: 311-322, 2019. PMID: 30725426. DOI: 10.1007/978-1-4939-8796-2_24

46 Kawaguchi K, Han Q, Li S, Tan Y, Igarashi K, Murakami T, Unno $M$ and Hoffman RM: Efficacy of recombinant methioninase (rMETase) on recalcitrant cancer patient-derived orthotopic xenograft (PDOX) mouse models: A review. Cells 8(5):410, 2019. PMID: 31052611. DOI: 10.3390/cells8050410

47 Park JH, Zhao M, Han Q, Sun Y, Higuchi T, Sugisawa N, Yamamoto J, Singh SR, Clary B, Bouvet M and Hoffman RM: Efficacy of oral recombinant methioninase combined with oxaliplatinum and 5-fluorouracil on primary colon cancer in a patient-derived orthotopic xenograft mouse model. Biochem Biophys Res Commun 518(2): 306-310, 2019. PMID: 31421825. DOI: $10.1016 /$ j.bbrc.2019.08.051

48 Oshiro H, Tome Y, Kiyuna T, Yoon SN, Lwin TM, Han Q, Tan Y, Miyake K, Higuchi T, Sugisawa N, Katsuya Y, Park JH, Zang Z, Razmjooei S, Bouvet M, Clary B, Singh SR, Kanaya F, Nishida $\mathrm{K}$ and Hoffman RM: Oral recombinant methioninase overcomes colorectal-cancer liver metastasis resistance to the combination of 5-fluorouracil and oxaliplatinum in a patient-derived orthotopic xenograft mouse model. Anticancer Res 39(9): 4667-4671, 2019. PMID: 31519565. DOI: 10.21873/anticanres.13648

49 Park JH, Han Q, Zhao M, Tan Y, Higuchi T, Yoon SN, Sugisawa $\mathrm{N}$, Yamamoto J, Bouvet M, Clary B, Singh SR and Hoffman RM: Oral recombinant methioninase combined with oxaliplatinum and 5-fluorouracil regressed a colon cancer growing on the peritoneal surface in a patient-derived orthotopic xenograft mouse model. Tissue Cell 61: 109-114, 2019. PMID: 31759402. DOI: 10.1016/j.tice.2019.09.006

50 Higuchi T, Han Q, Miyake K, Oshiro H, Sugisawa N, Tan Y, Yamamoto N, Hayashi K, Kimura H, Miwa S, Igarashi K, Bouvet M, Singh SR, Tsuchiya $\mathrm{H}$ and Hoffman RM: Combination of oral recombinant methioninase and decitabine arrests a chemotherapy-resistant undifferentiated soft-tissue sarcoma patient-derived orthotopic xenograft mouse model. Biochem Biophys Res Commun 523(1): 135-139, 2020. PMID: 31839218. DOI: $10.1016 /$ j.bbrc.2019.12.024

51 Tashiro Y, Han Q, Tan Y, Sugisawa N, Yamamoto J, Nishino H, Inubushi S, Higuchi T, Aoki T, Murakami M and Hoffman RM: Oral recombinant methioninase prevents obesity in mice on a high-fat diet. In Vivo 34(2): 489-494, 2020. PMID: 32111745. DOI: 10.21873/invivo.11799

52 Tashiro Y, Han Q, Tan Y, Sugisawa N, Yamamoto J, Nishino H, Inubushi S, Sun YU, Lim H, Aoki T, Murakami M, Takahashi Y, Bouvet $\mathrm{M}$ and Hoffman RM: oral recombinant methioninase prevents nonalcoholic fatty liver disease in mice on a high fat diet. In Vivo 34(3): 979-984, 2020. PMID: 32354883. DOI: 10.21873/invivo.11866

53 Tashiro Y, Han Q, Tan Y, Sugisawa N, Yamamoto J, Nishino H, Inubushi S, Sun YU, Lim H, Aoki T, Murakami M, Takahashi Y, Bouvet $\mathrm{M}$ and Hoffman RM: Oral recombinant methioninase prevents nonalcoholic fatty liver disease in mice on a high fat diet. In Vivo 34(3): 979-984, 2020. PMID: 32354883. DOI: 10.21873/invivo.11866

54 Lim HI, Hamada K, Yamamoto J, Han Q, Tan Y, Choi HJ, Nam SJ, Bouvet $\mathrm{M}$ and Hoffman RM: Oral methioninase inhibits recurrence in a PDOX mouse model of aggressive triplenegative breast cancer. In Vivo 34(5): 2281-2286, 2020. PMID: 32871751. DOI: 10.21873 /invivo.12039

55 Sugisawa N, Hamada K, Han Q, Yamamoto J, Sun YU, Nishino $\mathrm{H}$, Kawaguchi K, Bouvet M, Unno $\mathrm{M}$ and Hoffman RM: Adjuvant oral recombinant methioninase inhibits lung metastasis in a surgical breast-cancer orthotopic syngeneic model. Anticancer Res 40(9): 4869-4874, 2020. PMID: 32878774. DOI: 10.21873/anticanres.14489

56 Sun YU, Nishino H, Sugisawa N, Yamamoto J, Hamada K, Zhu G, Lim HI and Hoffman RM: Oral recombinant methioninase sensitizes a bladder cancer orthotopic xenograft mouse model to low-dose cisplatinum and prevents metastasis. Anticancer Res 40(11): 6083-6091, 2020. PMID: 33109546. DOI: $10.21873 /$ anticanres.14629

57 Lim HI, Yamamoto J, Han Q, Sun YU, Nishino H, Tashiro Y, Sugisawa N, Tan Y, Choi HJ, Nam SJ, Bouvet M and Hoffman RM: Response of triple-negative breast cancer liver metastasis to oral recombinant methioninase in a patient-derived orthotopic xenograft (PDOX) model. In Vivo 34(6): 3163-3169, 2020. PMID: 33144420. DOI: 10.21873/invivo.12151

$58 \mathrm{Wu}$ NF, Yamamoto J, Bouvet M and Hoffman RM: A novel procedure for orthotopic tibia implantation for establishment of a more clinical osteosarcoma PDOX mouse model. In Vivo 35(1): 105-109, 2021. PMID: 33402455. DOI: 10.21873/invivo.12237

59 Tan Y, Xu M, Tan X, Tan X, Wang X, Saikawa Y, Nagahama T, Sun X, Lenz M and Hoffman RM: Overexpression and largescale production of recombinant L-methionine-alpha-deaminogamma-mercaptomethane-lyase for novel anticancer therapy. Protein Expr Purif 9(2): 233-245, 1997. PMID: 9056489. DOI: 10.1006/prep.1996.0700

60 Ratan R and Patel SR: Chemotherapy for soft tissue sarcoma. Cancer 122(19): 2952-2960, 2016. PMID: 27434055. DOI: 10.1002/cncr.30191

61 Marchetto A, Ohmura S, Orth MF, Knott MML, Colombo MV, Arrigoni C, Bardinet V, Saucier D, Wehweck FS, Li J, Stein S, Gerke JS, Baldauf MC, Musa J, Dallmayer M, Romero-Pérez L, Hölting TLB, Amatruda JF, Cossarizza A, Henssen AG, Kirchner T, Moretti M, Cidre-Aranaz F, Sannino G and Grünewald TGP: Oncogenic hijacking of a developmental transcription factor evokes vulnerability toward oxidative stress in Ewing sarcoma. Nat Commun 11(1): 2423, 2020. PMID: 32415069. DOI: $10.1038 / \mathrm{s} 41467-020-16244-2$
Received March 1, 2021

Revised March 9, 2021

Accepted March 10, 2021 